\title{
Arpa (Hordeum vulgare L.) Köy Çeșitlerinde Tane Verimi ve Bazı Tarımsal Özelliklerin İncelenmesi
}

\author{
*Namuk ERGÜN", Sinan AYDOĞAN", İsmail SAYIM", \\ Aziz KARAKAYA², Arzu ÇELIK OĞUZ²

\begin{abstract}
${ }^{1}$ Tarla Bitkileri Merkez Araștırma Enstitüsü Müdürlüğü, Yenimahalle, Ankara
${ }^{2}$ Ankara Üniversitesi, Ziraat Fakültesi Bitki Koruma Bölümü, Dıșkapı, Ankara

*Sorumlu yazar e-posta (Corresponding author; e-mail): namuk.ergun@tarim.gov.tr
\end{abstract}

Geliș Tarihi (Received): 13.10.2017～Kabul Tarihi (Accepted): 14.11.2017

\begin{abstract}
Öz
Köy çeșitleri, özellikle kuru tarım alanlarında yürütülen ıslah programlarının en önemli gen kaynaklarından biridir. Seleksiyonda kullanılacak veya bir ıslah programında ebeveyn olarak yararlanılacak köy çeșitlerinin genetik varyasyon sınırlarının belirlenmesi ve hedef çevrelerdeki mevcut çeșitlere göre üstün olanların saptanması ıslah çalıșmasındaki bașarının arttırılması için gereklidir. Ankara-Gölbașı koșullarında 20122013 yetiștirme sezonunda yürütülen bu çalıșmada, arpa (Hordeum vulgare L.) köy çeșitlerinin verim ve bazı tarımsal özellikleri bakımından değișim sınırları ve üstün özellikler tașıyanların ıslah programlarında kullanım olanakları incelenmiștir. Araștırmada, 200 arpa köy çeșidi ile birlikte kontrol olarak ikisi altı sıralı ve üçü iki sıralı olmak üzere beș adet tescilli arpa çeșidi kullanılmıștır. Augmented deneme deseninde yürütülen bu araștırmada, bașaklanma süresi 172-194 gün, olgunlașma süresi 216-240 gün, bitki boyu 82-134 cm, m²'de bașak sayısı 204-796 adet, tane verimi 150.0-742.6 kg da-1 ve bin tane ağılığı 31.5-53.2 g arasında değișim göstermiștir. İncelenen özellikler içerisinde en yüksek değișime $\mathrm{m}^{2}$ 'de bașak sayısı, tane verimi ve bin tane ağırlığında rastlanmıș, araștırmada kullanılan köy çeșitlerinin tane verimleri üzerine en yüksek etkinin $\mathrm{m}^{2}$ 'de bașak sayısı olduğu saptanmıștır. Çalıșmada değerlendirilen köy çeșitlerinin verim ve tarımsal özellikleri bakımından incelenmesi sonucunda, bu materyalin Orta Anadolu'nun kuru koșullarında yürütülen bir arpa ıslahı programında gerek doğrudan çeșit tesciline yönelik gerekse melezleme programında genetik materyal olarak kullanma potansiyeline sahip olduğu görülmüștür.
\end{abstract}

Anahtar Kelimeler: Arpa, köy çeșitleri, tane verimi, tarımsal özellikler

\section{Investigation of Yield and Some Agronomic Traits on Barley (Hordeum vulgare L.) Landraces}

\section{Abstract}

Landraces are one of the most important genetic resources in breeding programs carried out especially in dry farming areas. Determination of genetic variation of landraces which will be utilized in selection or crossing programs as a parent in a breeding program and determining the superior genotypes better than the existing cultivars in the target environment is required to improve the success of breeding activities. In this study, variation range for grain yield and some agronomic traits of barley (Hordeum vulgare L.) landraces were investigated during 2012/2013 cropping year at Ankara-Golbasi location, in order to determine outstanding barley landraces and to utilize them in the barley breeding programs. Two hundred barley landraces including five check cultivars (three two-rowed and two six-rowed) were used as genetic materials. The design of the experiment was Augmented Experimental Design with four blocks. Minimum and maximum values of the genotypes revealed great variation among the genotypes. The range of the values were 172-194 days for days to heading, 216-240 days for days to maturity, $82-134 \mathrm{~cm}$ for plant height, 204-796 for spike number per $\mathrm{m}^{2}, 1500-7426 \mathrm{~kg} \mathrm{ha}^{-1}$ for grain yield and 31.5-53.2 $\mathrm{g}$ for thousand kernel weight. The highest variation in investigated traits was observed in spike number per $\mathrm{m}^{2}$, grain yield and thousand kernel weight. Spike number per $\mathrm{m}^{2}$ had the highest effect on grain yield of landraces used in this study. As a result of evaluation in terms of grain yield and agronomic traits of landraces, it was seen that these landraces material have a potential to use for direct registration or as a genetic material in crossing programs of a barley breeding program carried out in dry conditions of Central Anatolia.

Keywords: Barley, landraces, grain yield, agronomic traits 


\section{Giriș}

Arpa (Hordeum vulgare L.), Türkiye'de çoğunlukla kuru tarım alanlarında yağıșa bağımlı olarak yetiștirilen önemli bir tahıl cinsidir. Ülkemizde yaklașık \%90 oranında hayvan yemi olarak üretilen arpa ekim alanlarında son yıllarda daralma görülmektedir (Ergün et al. 2012; Anonim 2016). Ekim alanlarındaki bu daralmaya karșın nüfusun artan ihtiyacının karșılanması için birim alandan elde edilen ürün miktarının ve kalitenin arttırıması gerekmektedir. Arpa Islah çalıșmalarında verim ve verime etkili unsurların iyileștirilmesinde en önemli kaynaklardan biri de yerel popülasyonlar diğer bir deyișle köy çeșitleridir (Șehirali ve Özgen 1987; Ceccarelli and Grando 2000). Köy çeșitlerinin uzun zamandan beri aynı ya da yakın çevrelerde yetiștirilmesi, özellikle kendi coğrafyasında uzun bir doğal seleksiyon sürecinden geçmiș olması, birçok biyotik stres unsurlarına karșı dayanıklılık genleri tașımalarını ve içeriklerinde abiyotik stres koșullarına toleransta çok zengin bir varyasyonu barındırmalarını sağlamaktadır (Șehirali ve Özgen 1987). Aynı zamanda köy çeșitlerinin daha az miktarda gübre ve zirai ilaç kullanılarak yetișebilme becerisi onların stres koșullarına uygun agronomik özellikleri tașımalarından kaynaklanmaktadır. Türkiye, arpanın ilk kültüre alındığı, önemli gen merkezlerinden biridir (Harlan and Zohary 1966; Gökgöl 1969). Bu açıdan Türkiye'de arpanın geniș bir genetik çeșitliliği ve yetiștirme kültürü vardır (Gökgöl 1969; Fırat and Tan 1998). Günümüzde gen bankaları ve ıslah programlarının koleksiyonlarında çok sayıda köy çeșidi muhafaza edilmektedir. Köy çeșitlerindeki genetik potansiyel, onların ıslah amaçları doğrultusundaki özelliklerinin tespiti, üstün olanların belirlenmesi ve ıslah programlarında kullanılmaları ile yararlı hale gelebilir (Caccerelli and Grando 2000; Kolodinska-Brantestam et al. 2008).
Bu çalıșmada çoğu Türkiye orijinli 200 arpa köy çeșidinin verim ve bazı tarımsal özellikleri bakımından değișim sınırları kontrol çeșitleri ile karșılaștırmalı olarak incelenerek, Islah amaçları doğrultusunda üstün özellik gösterenlerin arpa ıslah programına dahil edilmesi amaçlanmıștır.

\section{Materyal ve Yöntem}

$\mathrm{Bu}$ çalıșmada bitki materyali olarak Tarla Bitkileri Merkez Araștırma Enstitüsü arpa ıslah programında 2010/2011 yetiștirme sezonunda tek bașak seleksiyonu ile saflaștırılan 174'ü iki, 26'sı altı sıralı 200 arpa köy çeșidi ile kontrol olarak Bülbül-89, Tarm-92, Aydanhanım, Avcl-2002 ve Çetin-2000 tescilli arpa çeșitleri kullanılmıștır. Denemeler 2012/2013 yetiștirme sezonunda İkizce (Gölbașı/ Ankara) lokasyonunda Augmented deneme desenine (Peterson 1994) göre dört blokta yürütülmüștür. Her blok elli beș parselden olușmuș ve bunların beș tanesine kontrol çeșitleri tekerrürlü, diğer elli tanesine ise denemeye alınan arpa köy çeșitleri tekerrürsüz olarak ekilmiștir. Denemenin kurulduğu alan toprak bakımından incelendiğinde, yüksek kireç oranı (\%23.2), yüksek yarayıșlı potasyum (365.6 kg da-1), hafif alkalik özellikli pH (7.86) ve düșük organik madde (\%1.15) miktarı ile Orta Anadolu Bölgesinin genel toprak özelliğini temsil ettiği görülmektedir (Çizelge 1).

Denemenin ekimi 23 Ekim 2012 tarihinde, $4 \mathrm{~m}$ uzunluğunda 6 sıradan (sıra arası $18 \mathrm{~cm}$ ) olușan parsellere $\mathrm{m}^{2}$ ye 500 tohum düșecek șekilde yapılmıștır. Gübre olarak, fosforun tamamı $\left(7 \mathrm{~kg} \mathrm{P} \mathrm{O}_{2} / \mathrm{da}\right)$ ve azotun yarıs ( $3.5 \mathrm{~kg}$ $\mathrm{N} / \mathrm{da}$ ) ekimle birlikte Diamonyum Fosfat (DAP) formunda ekim derinliğine uygulanmıștır. Azotlu gübrenin diğer yarısı \%33'lük Amonyum Nitrat formunda ( $3.5 \mathrm{~kg} \mathrm{~N} / \mathrm{da}$ ) Nisan ayı içinde parsellere uygulanmıștır. Yabancı ot mücadelesi gübrelemeyi takip eden günlerde

Çizelge 1. Araștırma parsellerinin toprak özellikleri, Gölbașı (Ikizce), Ankara

Table 1. Soil characteristics of experimental area, Gölbașı (ikizce), Ankara

\begin{tabular}{cccccc}
\hline $\begin{array}{c}\text { Toplam } \\
\text { Tuz }(\%)\end{array}$ & $\begin{array}{c}\text { Su ile doymuș } \\
\text { toprakta pH }\end{array}$ & $\begin{array}{c}\text { Kireç } \\
\left(\mathrm{CaCO}_{3}\right)(\%)\end{array}$ & $\begin{array}{c}\text { Faydalı Fosfor } \\
\left(\mathrm{P}_{2} \mathrm{O}_{5}\right)\left(\mathrm{kg} \mathrm{da}^{-1}\right)\end{array}$ & $\begin{array}{c}\text { Faydalı } \\
\text { Potasyum }\left(\mathrm{K}_{2} \mathrm{O}\right) \\
\left(\mathrm{kg} \mathrm{da}^{-1}\right)\end{array}$ & $\begin{array}{c}\text { Organik Madde } \\
(\%)\end{array}$ \\
\hline 0.085 & 7.86 & 23.2 & 8.1 & 365.6 & 1.15 \\
\hline
\end{tabular}


yabancı otların durumuna göre dekara 150 $\mathrm{g}$ etkili madde gelecek șekilde 2.4-D ester içerikli ot öldürücü kullanılarak yapılmıștır (Avcı and Akar 1998). Yine bu dönemde bloklar arasında çıkan yabancı otlar çapa makinesi ile temizlenmiștir.

Ekimin yapıldığı ve takip eden dönemde deneme yerinin aylık yağıș ve ortalama sıcaklık değerleri çimlenme ve ilk gelișme için yeterli olmuștur (Çizelge 2). Aralık, Ocak ve Șubat ayları toplam yağıș miktarı uzun yıllar ortalamasının bir miktar üzerinde gerçekleșmiștir. Kıș ayları boyunca ve Mart, Nisan aylarında ortalama hava sıcaklıklarının uzun yıllara göre $2-3{ }^{\circ} \mathrm{C}$ daha yüksek geçtiği görülmektedir (Çizelge 2). Bu dönemde yeterli nemin de olması nedeniyle bütün genotipler ortalama yıllara göre fenolojik olarak 10-15 gün ileride bir gelișme göstermiștir. Özellikle Orta Anadolu gibi tahıl tarımının yağıșa bağlı olarak gerçekleștiği alanlarda bitki gelișimi ve tane verimi için önemli olan Mart, Nisan ve Mayıs ayı yağıșları toplamda uzun yıllar ortalamasının yaklașık $25 \mathrm{~mm}$ üzerinde gerçekleșmiș, bu durum bitkilerin gelișimine olumlu yansıyarak verim değerlerinde artıșa yol açmıștır.

Denemenin hasadı 10 Temmuz 2013 tarihinde parsel biçerdöveri ile yapılmıș, kenar etkisini gidermek için hasattan önce yanlardan birer sıra ve parselin her iki tarafından $50 \mathrm{~cm}$ 'lik bölüm çıkartılmıștır. Bitkilerin gelișme süresi boyunca verimle ilișkili tarımsal gözlemler ve ölçümler Ergün ve Geçit (2008)'e göre așağıdaki gibi yapılmıștır.

Bașaklanma Süresi (gün): Çıkıștan itibaren her parseldeki bitkilerin ana saplarının \%50'sinin bașaklandığı devreye kadar geçen süre,

Olgunlașma Süresi (gün): Çıkıș tarihi ile hasat olgunluğu arasındaki süre olarak belirlenmiștir.

Bitki Boyu: Her parselden tesadüfen seçilen 20 adet bitkide toprak seviyesinden, kılçıklar hariç son bașakçığın ucuna kadar olan mesafe ölçülerek cm cinsinden belirlenmiștir.

Metrekarede bașak sayısı: Olgunlașma döneminde her parselin hasat alanı içinde kalan üç sıradan rastgele seçilen birer metrekarelik kısımda fertil bașaklar sayılarak bulunmuștur.

Bin Tane Ağırlığı: Parsellerden elde edilen tohumlardan dört tekrarlamalı olarak 100'er adet tohum sayılarak, hassas terazide tartılip ortalaması 10 ile çarpılarak gram (g) olarak hesaplanmıștır.

Tane verimi: Hasat zamanında parsellerde hasat alanı olarak belirlenen alanlar hasat edildikten sonra taneler tartılarak $\mathrm{kg} \mathrm{da}^{-1}$ cinsinden belirlenmiștir.

Bu ölçümlerden ve gözlemlerden elde edilen değerler, her bir özellik için ayrı olmak üzere, Augmented deneme desenine göre varyans analizine tabi tutulmuștur. Önemlilik testleri

Çizelge 2. İkizce lokasyonunun 2012/2013 yetiștirme sezonu aylık yağıș ve sıcaklık verileri Table 2. 2012/2013 growing season and longterm monthly precipitation and temperature data of ikizce location

\begin{tabular}{ccccc}
\hline Aylar & \multicolumn{2}{c}{ Aylık Yağıș $(\mathrm{mm})$} & \multicolumn{2}{c}{ Aylık Ortalama Sıcaklık $\left({ }^{\circ} \mathrm{C}\right)$} \\
\hline Eylül & $2012-2013$ & Uzun Yıllar Ortalaması & $2012-2013$ & Uzun Yıllar Ortalaması \\
Ekim & 3.6 & 18.0 & 19.0 & 17.0 \\
Kasım & 46.3 & 22.7 & 14.5 & 11.5 \\
Aralık & 34.7 & 29.1 & 6.9 & 5.7 \\
Ocak & 60.4 & 37.7 & 1.3 & 0.9 \\
Șubat & 27.0 & 36.3 & 0.1 & -0.9 \\
Mart & 26.8 & 34.0 & 3.8 & 1.0 \\
Nisan & 37.2 & 35.7 & 6.5 & 5.1 \\
Mayıs & 49.4 & 40.2 & 10.0 & 9.7 \\
Haziran & 59.8 & 46.9 & 16.5 & 14.4 \\
\hline TOPLAM & 13.0 & 35.7 & 20.0 & 18.1 \\
\hline
\end{tabular}


F testi ile, ortalamaların farklılık gruplandırmaları Asgari Önemli Fark (AÖF) yöntemine göre yapılmıștır. Asgari Önemli Farklar, Peterson (1994)'a göre en yüksek ya da en az değeri veren kontrol çeșit ile köy çeșitlerinin karșılaștırıması için așağıdaki formülle hesaplanmıștır. Köy çeșitlerine ait değerler, bulundukları bloktaki kontrol çeșitlerin o bloktaki ortalamalarının kontrol çeșitlerin genel ortalamalarından olan sapmaları kadar bir düzeltme terimi yardımıyla düzeltilip, düzeltilmiș ortalamaları üzerinden değerlendirilmiștir.

$A O ̈ F=t_{\propto} \sqrt{\frac{(b+1)(k+1) H K O}{b k}}$

$A O ̈ F=$ Asgari Önemli Farkı,

$t_{\alpha}=(b-1)(k-1)$ serbestlik dereceli $\alpha=0.05$ düzeyindeki iki yönlü $t$ tablo değerini,

$b=$ Blok sayısını,

$k=$ Kontrol çeșit sayısını,

$H K O=$ Kontrol çeșitlerin incelenen özelliklerine ait varyans analizi tablosundaki Hatanın Kareler Ortalamasını ifade etmektedir.

\section{Bulgular ve Tartıșma}

Köy çeșitlerinin verim ve incelenen tarımsal özelliklerine ait veriler, Peterson (1994)'e göre aynı blokta yer alan kontrol çeșitlerin o bloktaki ortalamalarının kontrol çeșitlerin genel ortalamalarından olan sapmaları oranında bir düzeltme terimi yardımıyla düzeltilerek değerlendirilmiștir. Buna göre ilk ele alınan özellik olan bașaklanma süresi bakımından köy çeșitlerinde 172 (8 Mayıs 2013) ile 194 (30 Mayıs 2013) gün arasında değișen sürelerde bașaklanma olduğu ve ortalama bașaklanma süresinin 182 gün civarında gerçekleștiği görülmüștür (Çizelge 3). En erken bașaklanma 172 gün ile 27 numaralı genotipte, en geç bașaklanma ise 194 günlük bașaklanma süresi ile 5, 6, 106.107 ve 108 numaralı genotiplerde görülmüștür. En erken ve geç bașaklanan genotipler arasında 22 günlük bir fark olușmuștur. Kontrol çeșitleri arasında ise bașaklanma süreleri bakımından en erken ve en geç bașaklananlar arasında 10 günlük bir fark olușurken, Tarm-92 ve Bülbül-89 kontrol çeșitleri 180 ve 182 gün ile en erken bașaklanan çeșitler olmuștur. Aydanhanım çeșidi ise 190 günlük bir bașaklanma süresi göstermiș ve en geç bașaklanan kontrol çeșit olarak görülmüștür. Avcl-2002 ve Çetin-2000 çeșitleri ise 184 gün ile ortalama bașaklanma süresi civarında değer göstermișlerdir (Çizelge 4). Kontrol çeșitlere göre hatların durumları değerlendirildiğinde, 77 adet köy çeșidi en erken bașaklanan (180 gün) kontrol çeșit olan Tarm-92 çeșidinden daha erken bașaklanmıș, 23 adet köy çeșidi ise en geç bașaklanan (190 gün) Aydanhanım çeșidinden daha geç bașaklanmıșlardır. Diğer genotipler ortalama bașaklanma süresi civarında bașaklanma süreleri ile diğer kontrol çeșitleri olan Avcl2002 ve Çetin-2000'e yakın bașaklanma süreleri göstermișlerdir. Bașaklanma süresi, uygulanan yetiștirme tekniğine, genotipe ve çevre șartlarına bağlı olarak farklılık gösterirken, bașaklanma süresinin ve tane doldurma süresinin verim ile olumlu ilișkisinin olduğu ve özellikle kurak alanlarda erken bașaklanmanın verimi artırdığı bilinmektedir. Ayrıca özellikle kurak baskısı altındaki bölgelerde kuraktan kaçmanın önemli bir unsuru olan erkencilik

Çizelge 3. Arpa köy çeșitlerinin tanımlayıcı istatistikleri

Table 3. Descriptive statistics of barley landraces

\begin{tabular}{lcccccc}
\hline \multicolumn{1}{c}{ Özellikler } & En az & En yüksek & Ortalama \pm SH & SS & DK (\%) & AÖF \\
\hline Bașaklanma süresi (gün) & 172 & 194 & $182.6 \pm 0.38$ & 5.4 & 2.9 & 1.7 \\
Olgunlașma süresi (gün) & 216 & 240 & $228.5 \pm 0.35$ & 4.9 & 2.1 & 1.4 \\
Bitki boyu (cm) & 82 & 134 & $102.2 \pm 0.53$ & 7.4 & 7.3 & 2.5 \\
m²'de bașak sayısı $^{2}$ & 204 & 796 & $483.3 \pm 9.18$ & 129.8 & 26.8 & 89.6 \\
Bin tane ağırlığı (g) & 31.5 & 53.2 & $44.4 \pm 0.33$ & 4.7 & 10.6 & 2.2 \\
Tane verimi (kg da-1) & 150.0 & 742.6 & $481.4 \pm 8.88$ & 125.5 & 26.1 & 149.5 \\
\hline
\end{tabular}

SH: Ortalamanın standart hatası, SS: Standart sapma, DK (\%): Değișim katsayısı (\%), AÖF: En yüksek ya da en düșük değere sahip kontrol çeșitleri ile karșılaștırma için 0.05 önemlilik düzeyinde asgari önemli fark

SH: Standart error of mean, SS: Standard deviation, DK (\%): Coefficient of variation (\%), AÖF: Least significant differences at 0.05 probability level to compare with the maximum or minimum value of check cultivars 
Çizelge 4. Kontrol çeșitlerin tane verimi ve tarımsal özelliklerine ait ortalamalar Table 4. Means of grain yield and agronomic traits of check cultivars

\begin{tabular}{lcccccc}
\hline \multicolumn{1}{c}{ Çeșitler } & $\begin{array}{c}\text { Bașaklanma } \\
\text { süresi (gün) }\end{array}$ & $\begin{array}{c}\text { Olgunlașma } \\
\text { süresi (gün) }\end{array}$ & $\begin{array}{c}\text { Bitki boyu } \\
(\mathrm{cm})\end{array}$ & $\begin{array}{c}\mathrm{m}^{2} \text { de bașak } \\
\text { sayısı }\end{array}$ & $\begin{array}{c}\text { Bin tane } \\
\text { ağırlığı }(\mathrm{g})\end{array}$ & $\begin{array}{c}\text { Tane verimi } \\
\left(\mathrm{kg} \mathrm{da}^{-1}\right)\end{array}$ \\
\hline Avcı-2002 & $184 \pm 0.3 \mathrm{~b}^{*}$ & $233 \pm 0.3 \mathrm{~b}$ & $103 \pm 0.4 \mathrm{c}$ & $335 \pm 15.8 \mathrm{~d}$ & $33.2 \pm 0.6 \mathrm{c}$ & $489 \pm 38.2 \mathrm{c}$ \\
Aydanhanım & $190 \pm 0.5 \mathrm{a}$ & $237 \pm 0.3 \mathrm{a}$ & $115 \pm 1.0 \mathrm{a}$ & $449 \pm 5.2 \mathrm{c}$ & $47.5 \pm 0.4 \mathrm{a}$ & $602 \pm 16.3 \mathrm{~b}$ \\
Bülbül-89 & $182 \pm 0.3 \mathrm{c}$ & $231 \pm 0.3 \mathrm{c}$ & $108 \pm 0.6 \mathrm{~b}$ & $659 \pm 29.0 \mathrm{~b}$ & $44.8 \pm 0.2 \mathrm{~b}$ & $641 \pm 34.2 \mathrm{ab}$ \\
Çetin-2000 & $184 \pm 0.3 \mathrm{~b}$ & $232 \pm 0.3 \mathrm{c}$ & $103 \pm 1.2 \mathrm{c}$ & $306 \pm 4.0 \mathrm{~d}$ & $32.1 \pm 0.2 \mathrm{c}$ & $423 \pm 7.5 \mathrm{c}$ \\
Tarm-92 & $180 \pm 0.3 \mathrm{~d}$ & $230 \pm 0.3 \mathrm{~d}$ & $109 \pm 0.9 \mathrm{~b}$ & $724 \pm 17.6 \mathrm{a}$ & $47.4 \pm 0.6 \mathrm{a}$ & $699 \pm 20.1 \mathrm{a}$ \\
Ortalama & 183.9 & 232.8 & 107.4 & 494.3 & 41.0 & 571 \\
AÖF (0.05) & 0.53 & 0.79 & 1.45 & 51.73 & 1.25 & 86.35 \\
\hline
\end{tabular}

*Aynı harfe sahip ortalamalar arasındaki fark istatistiki olarak 0.05 düzeyinde önemli değildir. AÖF (0.05): Asgari Önemli Fark

${ }^{*}$ There are no significant differences between the means with the same letters at 0.05 level. AÖF (0.05): Least Significant Difference

(Ceccarelli and Grando 2000; Samarah 2005; Araus et al. 2008; Bornare et al. 2012; Cavatte et al. 2012) bakımından öne çıkan $\% 30$ civarındaki genotipin bulunması bu materyalin erkencilik açısından ıslah programında kullanılabilecek seviyede olduğunu göstermektedir.

Olgunlașma süresinin köy çeșitleri arasında 216 (21 Haziran 2013) ile 240 (15 Temmuz 2013) gün arasında değiștiği ve ortalama olgunlașma süresinin 228 gün civarında olduğu saptanmıștır (Çizelge 3). En erken olgunlașan genotipler 216 gün ile 38, 88 ve 151 numaralı genotipler olurken, en uzun olgunlașma süresi ise 240 gün ile 58 numaralı genotipte görülmüștür. Kontrol çeșitleri arasında ise olgunlașma süreleri bakımından en erken ve en geç olgunlașanlar arasında 7 günlük bir fark olușurken, Tarm-92 ve Bülbül-89 kontrol çeșitleri sırasıyla 230 ve 231 gün ile en erken olgunlașan çeșitler olmuștur. Aydanhanım çeșidi ise 237 günlük bir olgunlașma süresi ile en geç olgunlașan kontrol çeșit olarak belirlenmiștir. Çetin-2000 ve Avcl-2002 çeșitleri ise sırasıyla 232 ve 233 gün ile ortalama olgunlașma süresinin bir miktar üzerinde değer göstermișlerdir (Çizelge 4). Kontrol çeșitlere göre hatların durumları değerlendirildiğinde 118 adet köy çeșidi en erken olgunlașan (230 gün) kontrol çeșit olan Tarm-92 çeșidinden daha erken olgunlașma süresi göstermiș, 13 adet materyal ise en geç olgunlașan (237 gün) Aydanhanım çeșidi ile aynı ya da daha geç olgunlașma süresine sahip olmuștur. Geri kalan materyal ortalama olgunlașma süresi civarındaki değerler almıșlardır.

Çalıșmada incelenen köy çeșitlerinin bitki boyları ortalaması $102 \mathrm{~cm}$ civarında olurken, en kısa bitki boyuna $82 \mathrm{~cm}$ ile 105 numaralı genotipte rastlanmıș, en uzun bitki boyu 134 cm ile 32 numaralı köy çeșidinde görülmüștür (Çizelge 3). Yaklașık \%7 lik bir varyasyonun görüldüğü bitki boyları bakımından materyalin

Çizelge 5. Kontrol çeșitlerin tane verimi ve tarımsal özelliklerine ait varyans analizi (ANOVA) Table 5. Analysis of variance (ANOVA) for grain yield and agronomic traits of check cultivars

\begin{tabular}{lcccccc}
\hline & $\begin{array}{c}\text { Serbestlik } \\
\text { Derecesi }\end{array}$ & $\begin{array}{c}\text { Kareler } \\
\text { toplamı }\end{array}$ & $\begin{array}{c}\text { Kareler } \\
\text { ortalaması }\end{array}$ & $F$ & $p$ & DK (\%) \\
\hline Bașaklanma süresi & 4 & 241.80 & 60.45 & 145.08 & $<, 0001$ & 0.3 \\
Olgunlașma süresi & 4 & 120.00 & 30.00 & 112.50 & $<, 0001$ & 0.2 \\
Bitki boyu & 4 & 433.30 & 108.33 & 121.49 & $<, 0001$ & 0.8 \\
m $^{2}$ de bașak sayısı & 4 & 571011.50 & 142752.90 & 126.61 & $<, 0001$ & 6.8 \\
Bin tane ağırlığı & 4 & 947.20 & 236.80 & 360.56 & $<, 0001$ & 2.0 \\
Tane verimi & 4 & 204173.28 & 51043.32 & 16.25 & $<, 0001$ & 9.8 \\
\hline
\end{tabular}

DK (\%): Değișim Katsayısı (\%)

DK (\%): Coefficient of variation (\%) 
büyük çoğunluğu (\%84-168 adet) 91-110 $\mathrm{cm}$ aralığında yani orta, orta-uzun grubunda yer almıștır. 10 adet genotip $90 \mathrm{~cm}$ ve altında bitki boyları ile kısa boylu olarak değerlendirilebilecek bitki boyu değerleri vermișlerdir. Yine 22 adet genotip 111-134 cm civarındaki boyları ile toplam materyal içinde $\% 11^{\prime}$ lik bir pay alarak uzun bitki boyuna sahip olmușlardır. Bitki boyu bakımından kontrol çeșitler incelendiğinde ise Çetin-2000 ve Avcl2002 çeșitleri 103 cm'lik boyları ile en kısa kontrol çeșitler olurken, Aydanhanım çeșidi $115 \mathrm{~cm}$ ile yüksek bitki boyuna sahip kontrol çeșit olmuștur. Tarm-92 ve Bülbül-89 çeșitleri ise sırası ile 109 ve $108 \mathrm{~cm}$ bitki boyları ile orta boylu grubuna yakın değerler vermișlerdir. Kontrol çeșitlere göre bitki boyu bakımından genotiplerin durumları değerlendirildiğinde ise 14 adet köy çeșidi en uzun kontrol çeșit olan Aydanhanım $(115 \mathrm{~cm})$ çeșidi ile aynı ya da daha uzun bitki boyuna sahip olmuștur. Buna karșın hatların yarısından fazlası (115 adet) $103 \mathrm{~cm}$ bitki boyuna sahip Çetin-2000 ve Avcl-2002 çeșitleri ile aynı ya da daha kısa bitki boyu değeri göstermișlerdir. Denemede bitki boyları arasında meydana gelen farkların hatların genetik yapıları ile birlikte deneme yılındaki ekolojik koșullara verdikleri tepkilerden kaynaklandığı düșünülmektedir. Özellikle Orta Anadolu gibi yağıșa bağımlı olarak tahıl tarımının yapıldığı bölgelerde yürütülen arpa ıslah programlarında, kuru koșullarda verim için önemli bir unsur olan bitki boyu (Gong et al. 2013; Kosova et al. 2014) bakımından, orta ve orta uzun bitki boyuna sahip genotipler seçilmektedir. Çalıșmada kullanılan materyalin de bitki boyu bakımından büyük bir kısmının orta, orta-uzun boylu grupta yer almasının bu materyalin daha önce agro-morfolojik olarak kuru koșullar için seçilmiș bir grubun içinden gelmesinden kaynaklandığı düșünülmektedir. Bunun yanında deneme materyali içinde sulu koșullar için değerlendirilebilecek kısa ve sağlam saplı, yatmaya dayanıklı köy çeșitleri de bulunmaktadır. Bu durum genotipler arasında bitki boyu bakımından olan varyasyonun yüksekliğini, dolayısıyla farklı amaç ve koșullar için kullanılabilecek özellikteki yeterli materyali barındırdığını göstermektedir.

Tane verimini en fazla ve doğrudan etkileyen verim unsurlarından biri olan birim alandaki bașak sayısı bakımından köy çeșitleri arasında \%26.8 gibi yüksek bir varyasyon görülmüștür. $\mathrm{Bu}$ verim unsuru bakımından köy çeșitleri incelendiğinde ortalamanın $\mathrm{m}^{2}$ de 483 bașak civarında olduğu, en yüksek değerin 796 ve 762 bașak sayısı ile sırasıyla 93 ve 196 numaralı genotiplerde yer aldığı saptanmıștır. En düșük bașak sayılarına ise 204 ve 228 bașak ile yine sırasıly 163 ve 102 numaralı hatlarda rastlanmıștır. Metrekarede bașak sayısı değerleri bakımından kontrol çeșitlerde en yüksek değere (724) Tarm-92 çeșidinde rastlanmıș, bunu 659 adet bașak sayısı ile Bülbül-89 takip etmiștir. En düșük bașak sayısına ise 306 bașak ile Çetin-2000 çeșidinde rastlanmıștır (Çizelge 4). Köy çeșitlerinin $\mathrm{m}^{2}$ 'de bașak sayısı bakımından kontrol çeșitlere göre durumu incelendiğinde 3 , 7, 10, 55, 92, 93, 143, 155, 175, 177 ve 196 numaralı genotipler, kontrol çeșitler içinde en yüksek bașak sayısına (724 bașak) sahip Tarm-92 çeșidinden daha yüksek $\mathrm{m}^{2}$ 'de bașak sayısına sahip olmuștur. Genotiplerin $\mathrm{m}^{2}$ 'de bașak sayıları bakımından dağılımlarına bakıldığında, materyalin çoğunluğunun (\%74.5) tane verimi bakımından küçümsenmeyecek bir rakam olan 400 bașaktan daha yukarıda $\mathrm{m}^{2}$ 'de fertil bașak sayılarına sahip olduğu görülmektedir. Bunun yanında en yüksek kontrol çeșitten daha yüksek değere sahip genotiplerin olması da bu materyal içerisinde verime doğrudan etki eden birim alan bașak sayısı bakımından yeterli genotipik potansiyelin olduğunu göstermektedir.

Çalıșmada yer alan materyalde bin tane ağırlığı bakımından \%10.6 lık bir varyasyona rastlanmıș, en yüksek ve en düșük bin tane ağırlıkları arasında 20 g'a yakın bir fark olușmuștur. Köy çeșitlerinin ortalama bin tane ağırlıkları 44.4 gram olurken (Çizelge $3)$, genotipler arasında en yüksek bin tane ağırlıkları $53.2 \mathrm{~g}$ ile 138 numaralı ve 52.9 $g$ ile 147 numaralı köy çeșitlerinden elde edilmiștir. En düșük bin tane ağırlıklarına ise 31.5 ve $31.6 \mathrm{~g}$ ile sırasıyla 17 ve 156 numaralı köy çeșitlerinde rastlanılmıștır. Çalıșmada kullanılan genotiplerden iki sıralılarda bin tane ağırlıkları ortalaması $45.7 \mathrm{~g}$ olurken, bu rakam altı sıralılarda $35.7 \mathrm{~g}$ olarak gerçekleșmiștir. Kontrol çeșitlerde en yüksek bin tane ağırlı̆̆ına $47.5 \mathrm{~g}$ ile Aydanhanım çeșidinde rastlanırken, bunu yakın bir değerle (47.4 g) Tarm-92 çeșidi 
izlemiștir. Altı sıralı kontrol çeșitler olan Avcı2002 ve Çetin-2000 çeșitleri ise 33.2 ve 32.1 g'ık bin tane ağırlıkları ile kontrol çeșitler arasında en düșük değere sahip olan çeșitler olmușlardır (Çizelge 4). Bin tane ağırlıkları bakımından köy çeșitleri ve kontrol çeșitler birlikte değerlendirildiğinde, köy çeșitleri arasından 57 adedi, en yüksek bin tane ağırlığına $(47.5 \mathrm{~g})$ sahip kontrol çeșit olan Aydanhanım'dan daha yüksek bin tane ağırlığı göstermiștir. Diğer taraftan en düșük bin tane ağırlığına sahip kontrol çeșit olan Çetin-2000 çeșidinin bin tane ağırlığından (32.1 g) daha düșük değer gösteren sadece 4 genotip görülmüștür. Bununla birlikte ortalama bin tane ağırığı civarı olan 45 g'dan daha yüksek değer gösteren 110 hattın olması bu materyalin iri ve dolgun taneli genotipleri barındırdığını, nișastanın fazlalığının ve yüksek ekstrakt oranının bir göstergesi (Kün 1996; Edney et al. 2005; Baik et al. 2011) olan bin tane ağırlığı bakımından oldukça yüksek bir potansiyele sahip olduğunu göstermektedir. Fiziksel kalite ölçütlerinden biri olan bin tane ağırlığı, bitkinin genetik yapısına (Hockett and Nilan 1985), birim alandaki fertil bașak sayısına (Budakli Carpici and Celik 2012), bașak sıra sayısına (Pomeranz 1976; Kolodinska-Brantestam et al. 2008), ekim zamanına (Kenar ve Șehirali 2001; Alam et al. 2007), ekim sıklığına (Lafond 1994; O'Donovan et al. 2012) ve çevre koșullarına göre farklılık göstermektedir. Bin tane ağırığının verime olan etkisinin bașaktaki tane sayısı ve birim alandaki bașak sayısına göre daha az etkili olduğu belirtilmektedir (Öztürk ve Akten 1999, Sönmez ve ark. 1999). Genel olarak Orta Anadolu kuru koșullarında iki sıralı arpaların bin tane ağırlığı altı sıralılara göre daha yüksek olmaktadır.

Köy çeșitlerinin tane verimleri incelendiğinde ortalamanın $481.4 \mathrm{~kg} \mathrm{da}^{-1}$ olduğu görülmüștür. Bu parametre bakımından 143 ve 196 numaralı genotipler sırasıyla 742.6 ve $736.7 \mathrm{~kg} \mathrm{da}^{-1}$ verim seviyeleri ile ilk sıralarda yer almıșlardır. En düșük tane verimleri ise 150.0 ve 185.8 $\mathrm{kg} \mathrm{da}^{-1}$ ile sırayla 82 ve 107 numaralı köy çeșitlerinden elde edilmiștir. İncelenen diğer özelliklere kıyasla tane verimi bakımından köy çeșitleri arasındaki değișim katsayısı \%26.1 gibi bir değerle oldukça yüksek bulunmuștur (Çizelge 3).
Kontrol çeșitlerin verim değerlerinden yapılan varyans analizi sonuçları incelendiğinde, tane verimleri bakımından kontrol çeșitler arasında istatistik olarak fark olduğu (Çizelge 5) en yüksek tane veriminin Tarm-92 çeșidine, en düșük tane veriminin ise Çetin-2000 çeșidine ait olduğu, diğer çeșitlerin bu iki çeșit arasında değer aldıkları görülmüștür (Çizelge 4). Buna göre kontrol çeșitleri ile köy çeșitlerinin tane verimi bakımından karșılaștırılmasında kullanılacak Asgari Önemli Fark değeri $149.5 \mathrm{~kg} \mathrm{da}^{-1}$ olarak hesaplanmıș (Çizelge 3) ve en yüksek kontrol çeșidin tane verimine ve kontrol çeșitlerin tane verimi ortalamasına göre köy çeșitlerinin durumları değerlendirilmiștir. En yüksek tane verimine sahip Tarm-92 çeșidinin $699 \mathrm{~kg} \mathrm{da}^{-1}$ 'llk verim seviyesinden daha yüksek verim seviyesine sahip dört genotip bulunurken $(93,143.177$ ve 196 numaralı hatlar) bu köy çeșitlerinin verim seviyeleri Tarm-92 çeșidi ile istatistik olarak aynı bulunmuștur. Buna karșılık kontrol çeșit ortalaması olan $571 \mathrm{~kg} \mathrm{da}^{-1}$ seviyesini geçen 53 genotip belirlenmiș, bunlardan üç tanesi (143, 177 ve 196) sirasiyla 743, 723 ve 737 $\mathrm{kg} \mathrm{da}^{-1}$ 'lık verim seviyeleri ile kontrol çeșit ortalamasından istatistik olarak daha yüksek tane verimine sahip olmuștur. Bunun yanında materyalin yaklașık \%25'lik bir kısmının kontrol ortalamasının üzerinde verim seviyesine sahip olması, bu materyalin tane verimi bakımından yeterli varyasyona ve potansiyele sahip olduğunun göstergesidir.

Çalıșmada köy çeșitlerinde ele alınan tarımsal özelliklerin tane verimi üzerine etkileri de incelenmiștir (Çizelge 6). Buna göre tane verimi üzerine en fazla ve pozitif (0.71) etkinin metrekarede bașak sayısında olduğu görülmüștür. Arpada yapılmıș diğer çalıșmalarda da (Acevedo 1987; Ataei 2006; Budakli Carpici and Celik 2012; Mehrdelan et al. 2013; Markova Ruzdik et al. 2015; Mohtashami 2015) benzer sonuçlara rastlamak mümkündür. Bunun yanında tane verimi ve bin tane ağırlığı arasında da olumlu (0.56) bir ilișki saptanmıștır. Bin tane ağırlığı bakımından gözlenen bu ilișki çalıșmada kullanılan iki sıralı ve bin tane ağırığı yüksek genotiplerin aynı zamanda verim bakımından da daha yüksek değerlere sahip olması ile açıklanabilir. Bitki boyunun tane verimine olan 
Çizelge 6. Köy çeșitlerinde tane verimi ve tarımsal özelliklere ait ilișkiler

Table 6. Correlation coefficients between grain yield and agronomic traits of landraces

\begin{tabular}{|c|c|c|c|c|c|}
\hline & $\begin{array}{l}\text { Olgunlașma } \\
\text { süresi }\end{array}$ & Bitki boyu & $\begin{array}{c}\mathrm{m}^{2} \text { de bașak } \\
\text { sayısı }\end{array}$ & Bin tane ağırlığı & Tane verimi \\
\hline Bașaklanma süresi & $0.81^{* *}$ & $-0.29^{\star \star}$ & $-0.28^{* *}$ & $-0.31^{* \star}$ & $-0.41^{\star \star}$ \\
\hline Olgunlașma süresi & & $-0.18^{\star}$ & $-0.20^{\star \star}$ & $-0.26^{\star *}$ & $-0.37^{\star \star}$ \\
\hline Bitki boyu & & & 0.13 & 0.09 & $0.23^{\star *}$ \\
\hline $\mathrm{m}^{2}$ de bașak sayısı & & & & $0.34^{* *}$ & $0.71^{* *}$ \\
\hline Bin tane ağırlığı & & & & & $0.56^{\star \star}$ \\
\hline
\end{tabular}

**istatistiki olarak 0.01 düzeyinde önemli, *istatistiki olarak 0.05 düzeyinde önemli.

${ }^{*}$ Statistically significant at 0.01 probability level, *Statistically significant at 0.05 probability level.

etkisi de yine olumlu yönde olmuștur (Çizelge 6). Yağıșa bağımlı tarımın yapıldığı kuru tarım alanlarında orta ve uzun boylu, üst boğum arası uzun genotiplerin kurağa olan toleransları ile verim bakımından üstün olmaları bu ilișkiyi açıklayabilir. Arpada verim ve verim unsurlarına yönelik önceki çalıșmalarda da (Madic et al. 2005; Markova Ruzdik et al. 2015) bitki boyunun tane verimine olumlu etkisi ile ilgili sonuçlara rastlanmıștır. İncelenen özellikler içerisinden bașaklanma zamanı ile tane verimi ve bin tane ağırlığı arasında negatif $(-0.41)$ bir ilișki tespit edilmiștir (Çizelge 6). Bunun sebebi olarak, kuru koșullarda arpa tarımının yapıldığı alanlarda erkenci ve orta-erkenci genotiplerin kuraktan kaçınmaları ile tane verimi ve tane iriliği açısından avantajı olmaları gösterilebilir (Samarah 2005; Mohammadi et al. 2006; Araus et al. 2008; Bornare et al. 2012; Cavatte et al. 2012).

\section{Sonuç}

Çalıșmada değerlendirilen köy çeșitlerinin verim ve tarımsal özellikleri bakımından incelenmesi sonucunda bu materyalin Orta Anadolu'nun kuru koșullarında yürütülen bir arpa ıslahı programında gerek doğrudan çeșit tesciline yönelik gerekse melezleme programında genetik materyal olarak kullanma potansiyeline sahip olduğu görülmüștür. Ayrıca materyal içerisinde erkencilik, bitki boyu ve bin tane ağırığı bakımından geniș bir varyasyonun olması bu materyalin farklı ıslah amaçları için de kullanılmasına olanak tanımaktadır.

İncelenen özelliklerden tane verimi üzerine en fazla $\mathrm{m}^{2}$ 'de bașak sayısının etkili olduğu görülmüștür. Bin tane ağırlığının da yine verim ile olumlu ilișki içerisinde olduğu belirlenmiștir. Çalıșmanın yürütüldüğü yıl ve materyalde geç bașaklanma ve olgunlașmanın ise tane verimini ve bin tane ağırlığını olumsuz yönde etkilediği gözlenmiștir.

Bu köy çeșitleri kullanılarak gerçekleștirilen bir çalıșmada arpa ağ benek hastalığının nokta ve ağ formlarına karșı dayanıklı genotipler bulunmuștur (Çelik Oğuz ve ark. 2017).

Bu materyalin çok lokasyonlu ve tekerrürlü denemeler ile adaptasyon sınırlarının belirlenmesi ve önemli diğer arpa hastalıklarına karșı olan reaksiyonlarının tespit edilmesi bu çalıșmadan elde edilen sonuçlara zenginlik kazandıracaktır.

\section{Teșekkür}

Bu çalıșma, TÜBITAK tarafından desteklenmiștir (Proje No: 1110644).

\section{Kaynaklar}

Acevedo E., 1987. Assessing crop and plant attributes for cereal improvement in waterlimited Mediterranean environments. In: Srivastava J.P., Porceddu E., Acevedo E., Varma S. (Eds.), Drought Tolerance in Winter Cereals, pp. 303-320. Wiley, Chichester, England

Alam M.Z., Haider S.A., and Paul N.K., 2007. Yield and yield components of barley (Hordeum vulgare L.) in relation to sowing times. Journal of Bio-Science, 15:139-145 DOI: 10.3329/jbs. v15i0.2154

Anonim, 2016. http://faostat.fao.org (Erișim tarihi: 07.03.2016)

Araus J.L., Slafer G.A., Royo C., and Serret M.D., 2008. Breeding for yield potential and stress adaptation in cereals. Critical Reviews in Plant Science, 27:377-412 DOI: $10.1080 / 07352680802467736$ 
Ataei M., 2006. Path analysis of barley (Hordeum vulgare L.) yield. Ankara Üniversitesi Ziraat Fakültesi Tarım Bilimleri Dergisi, 12(3):227-232

Avcı M., and Akar T., 1998. Adaptation of barley varieties to dryland environment of Central Anatolia. Journal of Central Research Institute for Field Crops, 7(2): 18-24

Baik B-K., Newman C.W., and Newman, R.K., 2011. Food uses of barley. In: Ullrich SE, (Ed.). Barley: Production, Improvement and Uses, pp. 532-562. Wiley-Blackwell, Chichester, UK

Bornare S.S., Prasad L.C., Prasad R., and Lal J.P., 2012. Perspective of barley drought tolerance; methods and mechanisms comparable to other cereals. Journal of Progressive Agriculture, 3:68-70

Budakli Carpici E., and Celik N., 2012. Correlation and path coefficient analyses of grain yield and yield components in two-rowed of barley (Hordeum vulgare convar. distichon) varieties. Notulae Scientia Biologicae,4(2):128-131

Cavatte P.C., Martins S.C.V., Morais L.E., Silva P.E.M., and DaMatta F.M., 2012. The physiology of abiotic stresses. In: Fritsche-Neto R., and Borém A. (Eds.), Plant Breeding for Abiotic Stress Tolerance, pp. 21-51. Springer-Verlag Berlin Heidelberg, DOI: 10.1007/978-3-64230553-5_3

Ceccarelli S., and Grando S., 2000. Barley landraces from the Fertile Crescent: a lesson for plant breeders. In: Brush, S.B. (Ed.) Genes in the field, on farm conservation of crop diversity. IPGRI Rome, IDRC Ottawa, Lewis Boca Raton

Çelik Oğuz A., Karakaya A., Ergün, N., and Sayim i. 2017. Turkish barley landraces resistant to net and spot forms of Pyrenophora teres. Phytopathologia Mediterranea 56: 217-223. DOI: 10.14601/Phytopathol_Mediterr-19659

Dyulgerova B., 2012. Correlations between grain yield and yield related traits in barley mutant lines. Agricultural Science and Technology, 4(3):208-210

Edney M.J., Izydorczyk M.S., Symons S.J., and Woodbeck N., 2005. Measuring barley kernel colour and size to predict end use malt quality. Canadian Grain Commission [Online] Available at: http://www.grainscanada.gc.ca/researchrecherche/edney/bcsq-ctoq/bcsq-ctoq-eng. htm

Ergun N., Aydogan S., and Sarı A.O., 2012. Cereal production and agronomic innovation in Turkey. Watch Letter, 23: 36-39

Ergün N. ve Geçit H.H., 2008. İleri kademe arpa (Hordeum vulgare L.) hatlarında verim ve verime etkili bazı karakterlerin incelenmesi. Ülkesel Tahıl Sempozyumu, 2-5 Haziran, Konya. s.1423

Firat A.E., and Tan A.,1998. Ecogeography and distribution of wild cereals in Turkey. In: Zencirci et al. (Eds.) The Proceeding of International Symposium on In situ Conservation of Plant Genetic Diversity, 81-85 CRIFC, Turkey
Gong X., Li C., Zhang G., Yan G., Reg Lance R., and Sun D., 2013. Novel genes from wild barley Hordeum spontaneum for barley improvement. In: Zhang G., Li C., Liu X. (Eds.) Advance in Barley Sciences: Proceedings of 11th International Barley Genetics Symposium, Zhejiang University Press and Springer Science+Business Media Dordrecht. pp. 69-86

Gökgöl M., 1969. Serin iklim hububatı ziraatı ve ıslahı (buğday, çavdar, arpa ve yulaf). Tarım Bakanlığı Ziraat İșleri Genel Müdürlüğü. 407 s. Özaydın Matbaası, İstanbul

Harlan J.R., and Zohary D., 1966. Distribution of wild wheats and barley. Science. 153: 10741080. DOI: 10.1126/science.153.3740.1074

Hockett E.A., and Nilan R.A., 1985. In: Rasmusson D.C. (Ed.), Genetics, Barley, Monograph:26, American Society of Agronomy, pp.190-216. Madison, WI

Kenar D. ve Șehirali S., 2001. Farklı ekim zamanlarının 2 ve 6 sıralı arpa çeșitlerinin verim ve verim öğeleri üzerine etkileri. Türkiye 4. Tarla Bitkileri Kongresi, s.177-182, Tekirdağ

Kolodinska-Brantestam A., von Bothmer R., Rashal I., Gullord M., Martynov S., and Weibull J., 2010. Variation of agronomic traits in Nordic and Baltic spring barley. In: Ceccarelli S., and Grando S. (Eds.) Proceedings of the 10th International Barley Genetics Symposium, 5-10 April 2008, Alexandria, Egypt. ICARDA

Kosova K., Vitamvas P., Urban M.O., Kholova J., and Prasil I.T., 2014. Breeding for enhanced drought resistance in barley and wheat - droughtassociated traits, genetic resources and their potential utilization in breeding programmes. Czech journal of genetics and plant breeding Genetika a šlechtění, 50(4):247-261

Kün E., 1996. Tahıllar-I (Serin İklim Tahılları). Ankara Üniversitesi Ziraat Fakültesi yayınları:1451 Ders kitabı: 322 s., Ankara

Lafond G.P., 1994. Effects of row spacing, seeding rate and nitrogen on yield of barley and wheat under zero-till management. Canadian Journal of Plant Science,74(4):703-711 DOI: 10.4141/ cjps94-127

Madic M., Paunovic A., Djurovic D., and Knezevic D., 2005. Correlations and "path" coefficient analysis for yield and yield components in winter barley. Acta Agriculturae Serbica, 10(20):3-9

Markova RuzdikN., Valcheva D., Vulchev D., Mihajlov Lj., Karov I., and llieva V., 2015. Correlation between grain yield and yield components in winter barley varieties. Agricultural Science and Technology, 7(1):40-44

Mehrdelan M., Marjani A., Reihani M., Ragbar T., and Masoumi K., 2013. Reviewing changes of yield relationship with yield components of promising genotypes of rainfed barley by path analysis. International Journal of Farming and Allied Sciences, 2(S):1226-1232 
Mohammadi M., Ceccarelli S., and Naghavi M.R., 2006. Drought tolerance in doubled haploid population of barley. International Journal of Agriculture and Biology, 5:694-697

Mohtashami R., 2015. The correlation study of important barley agronomic traits and grain yield by path analysis. Biological Forum- An International Journal 7(1):1211-1219

Muhe K., and Assefa A., 2011. Diversity and agronomic potential of barley (Hordeum vulgare L.) landraces in variable production system, Ethiopia. World Journal of Agricultural Sciences, 7(5):599-603

Öztürk A. ve Akten Ș., 1999. Kıșlık buğdayda bazı morfofizyolojik karakterler ve tane verimine etkileri. Turkish Journal of Agriculture and Forestry, 23(Ek Sayı 2):409-422

O'Donovan J.T., Turkington T.K., Edney M.J., Juskiw P.E., McKenzie R.H., Harker K.N., Clayton G.W., Lafond G.P., Grant C.A., Brandt S., Johnson E.N., May W.E., and Smith E., 2012. Effect of seeding date and seeding rate on malting barley production in western Canada. Canadian Journal of Plant Science, 92(2):321330. DOI: 10.4141/cjps2011-130

Peterson R.G., 1994. Agricultural Field Experiments: Design and Analysis (Books in Soils, Plants, and the Environment). Marcel Dekker, Inc., 409 p., Corvallis, Oregon
Pomeranz Y., Robbins G.S., Smith R.T., Craddock J.C., and Gilberston J.T., 1976. Protein content and amino acid composition of barley from the world collection. Cereal Chemistry, 53:497-504

Samarah N.H., 2005. Effects of drought stress on growth and yield of barley. Agronomy for Sustainable Development, 25:145-149

Sato K., Flavell A., Russell J., Börner A., and Valkoun J., 2014. Genetic diversity and germplasm management: wild barley, landraces, breeding materials. In: Kumlehn J., and Stein N. (Eds.), Biotechnological Approaches to Barley Improvement. Biotechnology in Agriculture and Forestry 69. 433 p. Springer-Verlag, Berlin, Heidelberg

Sönmez F., Ülker M., Yılmaz N., Ege H., Bürün B. ve Apak R., 1999. Tir buğdayında tane verimi ile bazı verim öğeleri arasındaki ilișkiler. Turkish Journal of Agriculture and Forestry, 23:45-52

Șehirali S. ve Özgen M., 1987. Bitkisel Gen Kaynakları. Ankara Üniversitesi Ziraat Fakültesi Yayınları:1020/294. 239 s, Ankara 